\title{
MENINGKATKAN HASIL BELAJAR SISWA DALAM PEMBELAJARAN IPS PADA MATERI MENCERITAKAN PENGALAMAN MELALUI METODE PEMBERIAN TUGAS DI KELAS II SDN 3 LIMBOTO KABUPATEN GORONTALO
}

\author{
Yusraningsih H. Pongoliu \\ Program Studi PGSD, Fakultas Keguruan dan IImu Pendidikan, Universitas \\ Muhammadiyah Gorontalo) \\ e-mail:yusraningsihpongoliu@umgo.ac.id
}

\begin{abstract}
This article is about improving student learning outcomes in social studies learning in the material retelling experience through the method of giving assignments in class // of SDN 3 Limboto. The purpose of the study was to improve student learning outcomes in social studies learning on the material retelling experience through assignment methods in class /I of SDN 3 Limboto. The research used was Classroom Action Research (CAR). This research was carried out in a cycle and each cycle consisted of 4 stages, namely the preparation stage, the implementation phase of the action, the monitoring and evaluation stage and the analysis and reflection stages. Based on the results of the research in the first cycle the percentage of results achieved by the KKM was $44 \%$ or 8 students who had fulfilled expectations and $56 \%$ or as many as 10 students who still needed to pay attention to their learning outcomes. While in the second cycle, the KKM achievement percentage increased to $94 \%$ or 17 students who had fulfilled expectations compared to the first cycle and only $6 \%$ or as many as 1 student who still needed to pay attention to the learning outcomes.
\end{abstract}

Keywords: Learning Outcomes; Assignment Method

\begin{abstract}
Abstrak
Artikel penelitian ini mengenai meningkatkan hasil belajar siswa dalam pembelajaran IPS pada materi menceritakan kembali pengalaman melalui metode pemberian tugas di kelas II SDN 3 Limboto.Tujuan penelitian adalah untuk meningkatkan hasil belajar siswa dalam pembelajaran IPS pada materi menceritakan kembali pengalaman melalui metode pemberian tugas di kelas II SDN
\end{abstract}


3 Limboto penelitian yang digunakan adalah Penelitian Tindakan Kelas (PTK). Penelitian ini dilaksanakan secara bersiklus dan masing-masing siklus terdiri dari 4 tahapan yaitu tahap persiapan, tahap pelaksanaan tindakan, tahap pemantauan dan evaluasi dan tahap analisis dan refleksi. Berdasarkan hasil penelitian pada siklus I prosentase hasil capaian dari KKM sebesar $44 \%$ atau 8 orang siswa yang telah memenuhi harapan dan 56\% atau sebanyak 10 orang siswa yang masih perlu diperhatikan hasil belajarnya. Sedangkan pada siklus II, prosentase capaian KKM meningkat menjadi $94 \%$ atau 17 orang siswa yang telah memenuhi harapan dibandingkan dengan siklus I dan tinggal $6 \%$ atau sebanyak 1 orang siswa yang masih perlu diperhatikan hasil belajarnya.

Kata Kunci : Hasil Belajar; Metode Pemberian Tugas

\section{PENDAHULUAN}

Untuk meningkatkan hasil belajar siswa maka diperlukan suatu metode pembelajaran yang tepat, yang tidak hanya bersifat konvensional. Dalamhal ini guru diharapkan dapat melakukan perbaikan dengan melihat sejauh mana para siswa dapat menguasai suatu materi yang telah diajarkan dengan menggunakan strategi pembelajaran yang sesuai sehingga proses belajar mengajar menjadi lebih menarik dan tidak membosankan. Sehingga dapat diketahui faktor apa saja yang menyebabkan ketidak tuntasan belajar tersebut. Salah satunya adalah dengan melakukan pemilihan metode pembelajaran yang tepat serta sesuai dengan kebutuhan pembelajaran siswa. Adapun metode yang baik dilakukan adalah metode pemberian tugas. Metode inidi pandang cocokuntuk diterapkan pada pembelajaran IPS pada materi menceritakan pengalaman.

Menurut Wardani (2008:8.17) Pembelajaran IPS SD diarahkan untuk mempersiapkan peserta didik sebagai warga Negara yang menguasai pengetahuan (knowledge), keterampilan (skills), sikap dan nilai (attitudes and values) yang dapat digunakan sebagai kemampuan untuk memecahkan masalah pribadi atau masalah sosial serta kemampuan mengambil keputusan berpatisipasi dalam berbagai kegiatan kemasyarakatan agar menjadiwarga Negara yang baik.

$$
\text { Maufur (2010: 12) pada }
$$
hakikatnya metode adalah alat yang 
hanya sementara efektif untuk memudahkan mengajar bukan tujuan akhir yang diharapkan guru. Menurut Uno (2007:2) bahwa "metode pembelajaran adalah cara yang digunakan guru, yang dalam menjalankan fungsinya merupakan alat untuk mencapai tujuan pembelajaran ". Kriteria pemilihan metode pembelajaran disesuaikan dengan situasi dan kondisi peserta didik, serta karakteristik dari setiap indicator dan kompetensi yang hendak dicapai pada setiap mata pelajaran.

Roestiyah, (2012

mengemukakan bahwa teknik pemberian tugas atau resitasi biasanya digunakan dengan tujuan agar siswa memiliki hasil belajar yang lebih mantap, karena siswa melaksanakan latihan-latihan selama melakukan tugas sehingga pengalaman siswa mempelajari sesuatu dapat lebih terintegrasi. Hal itu terjadi disebabkan siswa mendalalami situasi atau pengalaman yang berbeda, waktu menghadapi masalah-masalah yang baru.

\section{METODE PENELITIAN}

Penelitian ini di laksanakan di kelas 3 Limboto. Subjek penelitian adalah siswa kelas II SDN 3 Limboto yang berjumlah 18 orang siswa yang terdiridari 10 orang laki-laki dan 8 orang perempuan. Ditetapkan di kelas II sebagai subjek penelitian tindakan kelas ini berdasarkan observasi yang dilaksanakan penliti sebelum penelitian bahwa di kelas II SDN 3 Limboto menjadi perhatian utama karena hasil belajar siswa dalam pembelajaran IPS pada materi menceritakan pengalaman masih rendah, oleh karena itu subyek penelitian tindakan kelas ini ditetapkan di kelas II SDN 3 Limboto. Variabel penelitian yang menjadi titik sasaran untuk menjawab permasalahan dalam penelitian ini adalah variabel input, variabel proses, variabel output. Prosedur penelitian ini dilaksanakan dalam dua siklus dengan tahap-tahap sebagai berikut: Tahap Persiapan, Tahap Pelaksanaan Tindakan, Tahap Pemantauan dan Evaluasi, Tahap Analisis dan Refleksi. Teknik pengumpulan data Observasi Tes Wawancara dan Dokumentasi. Teknik Analisis Data.

\section{HASIL DAN PEMBAHASAN}

Penelitian tindakan kelas ini dilaksanakan pada siswa kelas II SDN 3 Limboto Kabupaten Gorontalo dengan jumlah siswa 18 orang. Penelitian ini dilaksanakan dalam dua siklus perlakuan atau tindakan. Berikut adalah uraian hasil pelaksanaan tindakan pada 
setiap siklus pembelajaran.

Berdasarkan hasil observasi awal yang dilakukan oleh peneliti bahwa hasil belajar siswa pada pembelajaran IPS khususnya siswa kelas II pada materi menceritakan pengalaman masih rendah, dimana dari 18 orang siswa yang diobservasi terdapat 6 orang siswa atau $33,3 \%$ yang sudah baik hasil belajarnya, sedangkan sisanya 12 orang siswa atau $66,6 \%$ yang masih rendah hasil belajarnya. Oleh karena itu perlu dikembangkan strategi pembelajaran yang mengaktifkan siswa dalam pembelajaran. Salah satu metode yang cocok untuk mengembangkan hasil belajar tersebut adalah menggunakan metode pemberian tugas.

Pada pelaksanaan tindakan kelas ini, peneliti menyajikan materi menceritakan pengalaman melalui metode pemberian tugas dalam meningkatkan hasil belajar siswa kelas II SDN 3 Limboto Kabupaten Gorontalo. Siklus I dilaksanakan dalam waktu 1 (satu) kali pertemuan, dansiklus 2 dilaksanakandalamwaktu 1 (satu) kali pertemuan.

Hasil observasi awal yang dilakukan oleh peneliti SDN 3 Limboto Kabupaten Gorontalo khususnya pada siswa kelas II, bahwa hasil belajar siswa pada mata pelajaran IPS masih rendah, dimanadari 18 orang siswa yang di observasi terdapat 6 orang siswa atau $33,3 \%$ yang sudah baik hasil belajarnya, sedangkansisanya12 orang siswaatau $66,6 \%$ yang masih rendah hasil belajarnya. Oleh karena itu perlu dikembangkan strategi pembelajaran yang mengaktifkan siswa dalam pembelajaran. Salah satu metode yang cocok untuk mengembangkan hasil belajar tersebut adalah menggunakan metode pemberian tugas. Berdasarkan prosedur penelitian tindakan kelas, peneliti merancang pembelajaran yang dapat membuat siswa aktif dalam menerima pembelajaran sesuai dengan kelompok masing-masing melalui metode pemberian tugas.Adapun prosentasi capaian dalam meningkatkan hasil belajar siswa tentang menceritakan pengalaman dengan menggunakan metode pemberian tugas dapat dilihat dalam Tabel 1.

Pada 3 aspek yang diamati terlih atas pekperubahan sikap dalam diri siswa nilai baik dengan prosentase $44 \%$ atau 8 orang siswadan $56 \%$ atau 10 orang siswa masih kategori cukup, sementara pada aspek keberanian $6 \%$ sangat baik, $44 \%$ baik dan $50 \%$ masih kategori cukup dan dari aspek tingkat ketelitian $27 \%$ baik, $56 \%$ cukup dan $17 \%$ kurang.

Pada akhir pertemuan guru memberikan evaluasi, dimana evaluasi 
Tabel. 1 Hasil Capaian Siswa Pada Kegiatan Siklus I

\begin{tabular}{lccccccccccccc}
\hline & \multicolumn{1}{c}{ Keberanian } & \multicolumn{1}{c}{ Sikap } & \multicolumn{5}{c}{ Ketelitian } \\
\cline { 2 - 15 } & 4 & 3 & 2 & 1 & 4 & 3 & 2 & 1 & 4 & 3 & 2 & 1 \\
\hline Jumlah & 1 & 8 & 9 & 0 & 0 & 8 & 10 & 0 & 0 & 5 & 10 & 3 \\
Persentase (\%) & 6 & 44 & 50 & 0 & 0 & 44 & 56 & 0 & 0 & 27 & 56 & 17 \\
\hline
\end{tabular}

Tabel. 2 Hasil belajar pada siklus I

\begin{tabular}{lcc}
\hline & \multicolumn{2}{c}{ Penilaian KKM } \\
\cline { 2 - 3 } & Tuntas & Tdk. Tuntas \\
\hline Jumlah & 8 & 10 \\
Persentase (\%) & 44 & 56 \\
\hline
\end{tabular}

Tabel. 3 Hasil capaiansiswapadakegiatansiklus II

\begin{tabular}{lccccccccccccc}
\hline & \multicolumn{1}{c}{ Keberanian } & \multicolumn{1}{c}{ Aspek Diamati } \\
\cline { 2 - 16 } & 4 & 3 & 2 & 1 & 4 & 3 & 2 & 1 & 4 & 3 & 2 & 1 \\
\hline Jumlah & 8 & 9 & 1 & 0 & 9 & 7 & 2 & 0 & 2 & 9 & 5 & 2 \\
Persentase (\%) & 44 & 50 & 6 & 0 & 50 & 39 & 11 & 0 & 11 & 50 & 28 & 11 \\
\hline
\end{tabular}

ini bertujuan untuk mengetahui hasil belajar siswa secara individu pada pembelajaran yang telah dilakukan padahari itu. Sementara itu prosentasi hasil belajar pada materi menceritakan pengalaman dengan menggunakan metode pemberian tugas setelah dilakukan penindakan pada siklus I dapat dilihat dalam Tabel 2.

Tabel 2 membuktikan dengan persentase capai dari KKM sebesar $44 \%$ atau 8 orang siswa yang telah memenuhi harapan dibandingkan sebelum dilaksanakan metode pemberian tugas dan $56 \%$ atau sebanyak 10 orang siswa yang masih perlu diperhatikan hasil belajarnya. Dan untuk meningkatkan hasil belajar tersebut peneliti akan melakukan penyempurnaan materi, kesiapan materi melalui siklus II.

Berdasarkan hasil pengamatan kegiatan siswa pada siklus I, dan melihat hasil evaluasi capain siswa dalam menceritakan pengalaman melalui metode pemberian tugas belum mencukupi standar indicator kinerja atau belum tuntas, maka peneliti bersama guru pamong mengadakan kegiatan refleksi untuk 
menilai kegiatan pembelajaran yang dilaksanakan padasiklus I.

Berdasarkan hasil refleksi bersama bahwa untuk memperbaiki kelemahan-kelamahan yang terjadi pada pelaksanaan tindakan pada siklus I serta untuk mencapai indicator kinerja yang telah ditetapkan maka perlunya untuk dilaksanakan tindakan selanjutnya sebagai upaya penyempurnaan dari siklus sebelumnya.

Siklus II dilaksanakan dikarenakan belum mencapainya target atau belum terpenuhinya indikator kinerja yang telah ditetapkan. Hasil presentasi capaian siswa pada tindakan pembelajaran siklus II dengan menggunakan metode pemberian tugas dapat dilihat pada Tabel 3.

Dari 3 aspek yang diamatiter lihat aspek keberanian siswa nilai sangat baik dengan prosentase $44 \%$ atau 8 orang siswadan $50 \%$ atau 9 orang siswa masih kategori baik dan hanya $6 \%$ orang siswa yang kategori cukup, sementara pada aspek perubahan sikap $50 \%$ sangat baik, $39 \%$ baik dan $11 \%$ masih kategori cukup dan dari aspek tingkat ketelitian $11 \%$ sangatbaik, $50 \%$ baik, $28 \%$ cukup dan $11 \%$ kurang. Sementara prosentasi hasil belajar pada materi menceritakan pengalaman dengan menggunakan metode pemberian tugas setelah dilakukan penindakan pada siklus II dapat dilihat dalam Tabel 4

Setelah dilakukan evaluasi melalui tes pada siklus II, peneliti menilai hasil pengamatan tersebut sangat membantu siswa untuk dapat meningkatkan hasil belajarnya. Hal ini dibuktikan dengan prosentase capai dari KKM sebesar $94 \%$ atau 17 orang siswa yang telah memenuhi harapan dibandingkan dengan siklus I dan tinggal $6 \%$ atau sebanyak 1 orang siswa yang masih perlu diperhatikan hasil belajarnya.

Setelah diadakannya tindakan perbaikan pada kegiatan siklus II ini, hasil evaluasi dilakukan refleksi berdasarkan hasil pengamatan pada kegiatan siswa pada aspek Ketuntasan dalam menceritakan pengalaman dengan menggunakan metode pemberian tugas untuk kriteria tuntas telah mendominasi jika di rataratakan telah mencapai persentase rata-rata $85 \%$. Dan untuk hasil capain siswa pada siklus II ini untuk ketuntasan belajar telah mencapai 17 orang atau $94 \%$ maka dari hasil refleksi disimpulkan tidak perlu lagi 
dilanjutkan pada siklus berikutnya, karena dianggap telah berhasil/ tuntas sesuai pernyataan pada hipotesis tindakan dan indikator kinerja yang ditetapkan.

Berdasarkan standar yang telah ditetapkan pada indicator kinerja $75 \%$ maka penelitian tindakan kelas menunjukkan hasilsebagai berikut:

Tabel 4 Hasil belajar pada kegiatan siklus II

\begin{tabular}{lcc}
\hline & \multicolumn{2}{c}{ Kriteria } \\
\cline { 2 - 3 } & Tuntas & TdkTuntas \\
\hline Jumlah & 17 & 1 \\
Persentase (\%) & 94 & 6 \\
\hline
\end{tabular}

Gambar.1 Perbandingan Hasil Pengamatan observasi awal, siklus I dan Siklus II

\section{PENUTUP}

\section{Simpulan}

Hasil penelitian tindakan kelas

Tabel 5. Perbandingan Hasil Pengamatan

\begin{tabular}{|c|c|c|c|}
\hline \multirow[t]{3}{*}{ Kegiatan } & \multicolumn{2}{|c|}{ Jumlah } & \multirow{3}{*}{$\begin{array}{c}\text { Persentase } \\
\text { Ketuntasan } \\
(\%)\end{array}$} \\
\hline & Tuntas & Tidak & \\
\hline & & Tuntas & \\
\hline Observasi & 6 & 12 & 33,3 \\
\hline \multicolumn{4}{|l|}{ awal } \\
\hline Siklus I & 8 & 10 & 44 \\
\hline Siklus II & 17 & 1 & 94 \\
\hline
\end{tabular}

Dari tabel 5 dapat kita lihat perbandingan untuk observasi awal, siklus I dan siklus II dalam diagram berikut: yang dilaksanakan selama dua siklus dapat disimpulkan dengan menggunakan metode pemberian tugas pada siswa kelas II SDN 3 Limboto Kabupaten Gorontalo hasil belajar siswa tentang menceritakan pengalaman meningkat. Hasil observasi belajar siswa pada materi menceritakan pengalaman mata pelajaran IPS masih rendah, dimana dari 18 orang siswa yang diobservasi terdapat 6 orang siswa atau 33\% yang hasil belajarnya masih baik, sedangkan sisanya 12 orang siswa atau $67 \%$ hasil belajar masih sangat rendah. Hasil pelaksanaan siklus I 
Pada 3 aspek yang diamati terlihat aspek perubahan sikap dalam diri siswa nilai baik dengan prosentase $44 \%$ atau 8 orang siswa dan 56\% atau 10 orang siswa masih kategori cukup, sementara pada aspek keberanian $6 \%$ sangat baik, $44 \%$ baik dan $50 \%$ masih kategori cukup dan dari aspek tingkat ketelitian $27 \%$ baik, $56 \%$ cukup dan $17 \%$ kurang. Pada siklus II, 3 aspek yang diamati terlihat aspek keberanian siswa nilai sangat baik dengan prosentase $44 \%$ atau 8 orang siswa dan $50 \%$ atau 9 orang siswa masih kategori baik dan hanya $6 \%$ orang siswa yang kategori cukup, sementara pada aspek perubahan sikap $50 \%$ sangat baik, $39 \%$ baik dan $11 \%$ masih kategori cukup dan dari aspek tingkat ketelitian $11 \%$ sangat baik, $50 \%$ baik, $28 \%$ cukup dan $11 \%$ kurang. Hasil evaluasi berdasarkan hasil pengamatan pada kegiatan siswa dalam menceritakan pengalaman dengan menggunakan menggunakan metode pemberian tugas nampak telah didominasi oleh kriteria Tuntas $(\mathrm{T})$ dengan 17 siswa atau jika dipersentase 94\%. Dengan demikian hipotesis tindakan yang dirumuskan sebelumnya yaitu: "jika menggunakan metode pemberian tugas maka hasil belajar siswa tentang menceritakan pengalaman akan meningkat" .

\section{Saran}

Berdasarkan kesimpulan yang telah dipaparkan di atas, maka peneliti memberikan saran bahwa Penelitian tindakan kelas ini diharapkan menjadi acuan bagi sekolah, guru,dan siswa untuk dapat meningkatkan hasil belajar terutama pada pembelajaran IPS; Bagi peneliti itu sendiri sebagai suatu pengalaman dalam membelajarkan IPS dengan menggunakan metode pembelajaran yang tepat dan sesuai dengan tingkatan pola pikir siswa SD pada khususnya.

\section{DAFTAR PUSTAKA}

Maufur Hasan Fauzi. 2010. Sejuta Jurus Mengejar Mengasyikkan. Jawa Tengah: PT Sindur Press

Roestiyah, 2012. Strategi Belajar Mengajar. Jakarta: Rineka Cipta

Uno, Hamzah B. 2007. Model Pembelajaran. Jakarta: PT Bumi Aksara

Wardani, IG.A.K, dkk. Perspektif Pendidikan SD. Jakarta: Universitas Terbuka. 